\title{
The Role of Homegarden Agroforestry in Biodiversity Conservation at Yayo Coffee Forest Biosphere Reserve, Chora District, South-western Ethiopia
}

\author{
Gemeda Terfassa \\ Adami Tulu Agricultural Research Center, Oromia Agricultural Research Institute, Addis Ababa, Ethiopia
}

Email address:

gemedaterfassa@gmail.com

\section{To cite this article:}

Gemeda Terfassa. The Role of Homegarden Agroforestry in Biodiversity Conservation at Yayo Coffee Forest Biosphere Reserve, Chora District, South-western Ethiopia. Ecology and Evolutionary Biology. Vol. 6, No. 3, 2021, pp. 78-87. doi: 10.11648/j.eeb.20210603.12

Received: June 8, 2021; Accepted: July 13, 2021; Published: July 21, 2021

\begin{abstract}
Traditional homegardens in southwest Ethiopia is well-known land use practices playing important role in biodiversity conservation aspects. The objective of this study was to examine the contribution of homegardens towards of biodiversity conservation. Homegarden plant diversity assessment was done. A simple random sampling method was used to select 45 homegardens. Diversity indices were used for analysis. A total of 79 plant species belonging to 41 families were identified. Family Fabaceae and Rutaceae have a relatively higher number of species (6 species each). In terms of habit, (34\%) of the species were herbs followed by trees (30\%), shrubs (27\%) and climbers (9\%). Farmers manage both exotic (61\%) and indigenous (39\%), from which 57\% were food and 43\% nonfood plant species. The Shannon, Simpson and evenness diversity indexes were $3.27,0.053$ and 0.87 respectively. Coffea arabica was the most frequent $(86.67 \%)$ species followed by Persea americana (68.89) and Catha edulis (64.44) in homegardens of the area. This study suggests that homegardens contribute to plant biodiversity conservation in the study area. However, due to few market-oriented crops concentration, biodiversity of the system have been affected. Thus, gardeners should be encouraged to cultivate versatile plants in the practice for effective biodiversity conservation.
\end{abstract}

Keywords: Yayo, Coffee Forest, Biodiversity Hotspot, Buffer Zone, Cash Crop, Food Security

\section{Introduction}

\subsection{Background and Justification}

Agroforestry is a dynamic land use practices that maintain overall farm productivity by combining herbaceous food crops with woody perennial and livestock on the same piece of land. Homegardens are among agroforestry practices with the most complex and diverse agroecosystem that have been developed by numerous human cultures worldwide. They played an important role towards the development of early agriculture and domestication of crops. Homegardens often show a promising option for biodiversity conservation and mitigation of ecosystem degradation. In some cases, they were found to be equally effective as natural forests in the conservation of tree species diversity $[1,34,26]$.

In relation to conservation of biodiversity, [15], describes that homegardens are taken as key places for conserving plant biodiversity. It is exhibited that homegardens are serving as refugees camp for a number of plants species especially for those plant species that are not widely grown in the larger agroecosystem. They are microenvironments containing high levels of species and genetic diversity which serves not only as sources of food, fodder, fuel, medicines, spices, construction materials and income in many countries around the world, but are also important for in-situ conservation of a wide range of plant genetic resources. However, homegardens structure, composition, and species and cultivar diversity are influenced by changes in the socioeconomic circumstances and cultural values of the households that maintain these gardens [12].

Integrating multipurpose trees with food crops and livestock in homegardens in the intimate association is an ancient activity in Ethiopia [4]. According to [7], 
Ethiopian homegardens as an ecosystem encompass multiple levels of diversity, including cultural, genetic and agronomic diversity. About 539 species belonging to 352 genera and 109 families were recorded in Ethiopian homegardens which make up nearly $9 \%$ of the Ethiopian higher flora, were reported. Conversely, the recent transition of the homegardens into commercial production of new cash crops, including khat (Catha edulis) is a farming strategy undertaken by smallholders to address demographic, market and socioeconomic changes in the country. The changing socioeconomic conditions and advent of commercial forces have introduced the concept of cash with homegardens $[26,16]$.

On the other hand, the ongoing land fragmentation and the declining farm size in rural Ethiopia have limited the livelihood choices and opportunities of most smallholder farmers. The expansion of cultivated area is likely to require further infrastructure development that would result in further negative environmental implications with huge loss of biological diversity. In order to adapt to such socioeconomic changes, subsistence-oriented agroforestry homegardens are increasingly becoming more commercially oriented. This ongoing land use change has been carried out at the expense of diversity and stability of the long-existing farming practices important for sustainable livelihoods and food security $[19,43,34,16]$.

In addition, reduction of forest resources and increasing demand for its products especially in areas where people rely on natural resources for their livelihood needs are common. Finding alternative options to this widened gap between the demand and supply of forest products for local livelihood sustenance coupled with the natural resources conservation goal attainment is a fundamental concern. Homegarden seems to have the potential to provide options for sustained rural livelihoods and biodiversity conservation. It integrates protected areas with the surrounding landscapes and mediates the livelihood need of people within the conservation goal of the protected area. Thus it provides a potential to reduce land-use pressure and improve rural livelihoods in humandominated landscapes and at the same time conserving a large proportion of biodiversity [27].

Following the nomination of Yayo Coffee Forest Biosphere Reserve (YCFBR), as a site for biodiversity conservation in southwestern Ethiopia [19], the local people dependency on homegarden as an alternative option is increasing. However, less emphasis is given towards of assessing existing plant diversity in homegarden, particularly in Chora district. The homegardens potential for conservation of biological diversity and economic returns are not fully studied. Thus, there is no inventoried documentation about structure, composition and plant diversity for the district.

According to [3], to determine how homegardens can best contribute to conservation, it is necessary to understand what diversity is being maintained by farmers. Hence, in order to strengthen and make the existing practice effective for plant diversity conservation and thereby to meet the homegarden products for locals need, scientific information is required.
The study has a vital role for natural resources conservation and local people livelihood sustenance; it documents the role of homegarden towards of plant biodiversity conservation by describing floristic richness and diversity of the practice. It also describes their role to communities' livelihood, food security and income generation at the household level.

\subsection{Objective of the Study}

To assess and identify plant species composition and diversity of homegardens in the study area,

\subsection{Research Questions}

The study was aimed to address the following research question:

What is the plant species constitute of homegardens in the study area?

\section{Materials and Method}

\subsection{Description of the Study Area}

\subsubsection{Yayo Coffee Biosphere Reserve (YCFBR)}

The study area YCFBR is located in the Oromia state, southwestern Ethiopia, between $8^{\circ} 10^{\prime}-8^{\circ} 39^{\prime} \mathrm{N}$ and $35^{\circ} 30^{\prime}$ $36^{\circ} 4^{\prime} \mathrm{E}$. The area was registered in 2011 by the UNESCO as the 'Yayo Coffee Forest Biosphere Reserve' for the in-situ conservation of wild Coffea arabica. It covers about 167,021 ha split into six woreda 1, namely Algae Sachi, Bilo-Nopa, Chora, Doreni, Hurumu, and Yayo [19]. The area has a rolling topography where altitudes range from 1140 to 2562 $\mathrm{m}$ a.s.l., and is crossed by three major rivers, i.e., Geba, Dogi and Sese. The climate is hot and humid, and the mean annual temperature is around $20^{\circ} \mathrm{C}$ oscillating between the average extremes of $12^{\circ} \mathrm{C}$ and $29^{\circ} \mathrm{C}$. The area exhibits a uni-modal rainfall pattern with mean annual precipitation of $2100 \mathrm{~mm}$, with high disparity from year to year, and ranging from 1400 to $3000 \mathrm{~mm}$ [18]. Dominant soil groups include nitosols, acrisols, vertisols, and cambisols [42]. The reserve is managed in zones, so that smallholder farmers can still use forest resources sustainably. The core zone encompasses 27,733 ha of undisturbed natural forest; the buffer zone 21,552 ha of mostly semi-coffee forest, where restricted use of forest resources is allowed [40]. The research was conducted in the YCFBR areas (specifically in Hawayember, Sololo and Uta None kebeles of Chora district (Figure 1).

\section{(i) Population}

In 2007, around 310,000 people lived in the six woreda [9]. The Oromo ethnic group predominates and is considered indigenous. There are a significant number of Amhara, Tigreway and Kembata as they migrated from other parts of the country due to the government's forced resettlement program of 1984 [28]. Orthodox christian, muslim, protestant and indigenous beliefs are evenly practiced [25]. Currently, the population of Yayo is booming due to the high birth rate, and the intense internal migration due mainly to the thriving infrastructural development [46], such as the construction of 
fertilizer and coal factories, a network of roads planned to ease the trade of coffee, and the forthcoming hydroelectric dam on the Geba River.

\section{(ii) Land Use Systems}

The major land-use types are forest, agricultural land, wetland, and grazing land (Figure 2). Forests cover most of the area, and consist of four major variations, namely undisturbed natural forest, semi-forest coffee systems, fully managed forest for coffee production, and old secondary forests [19].

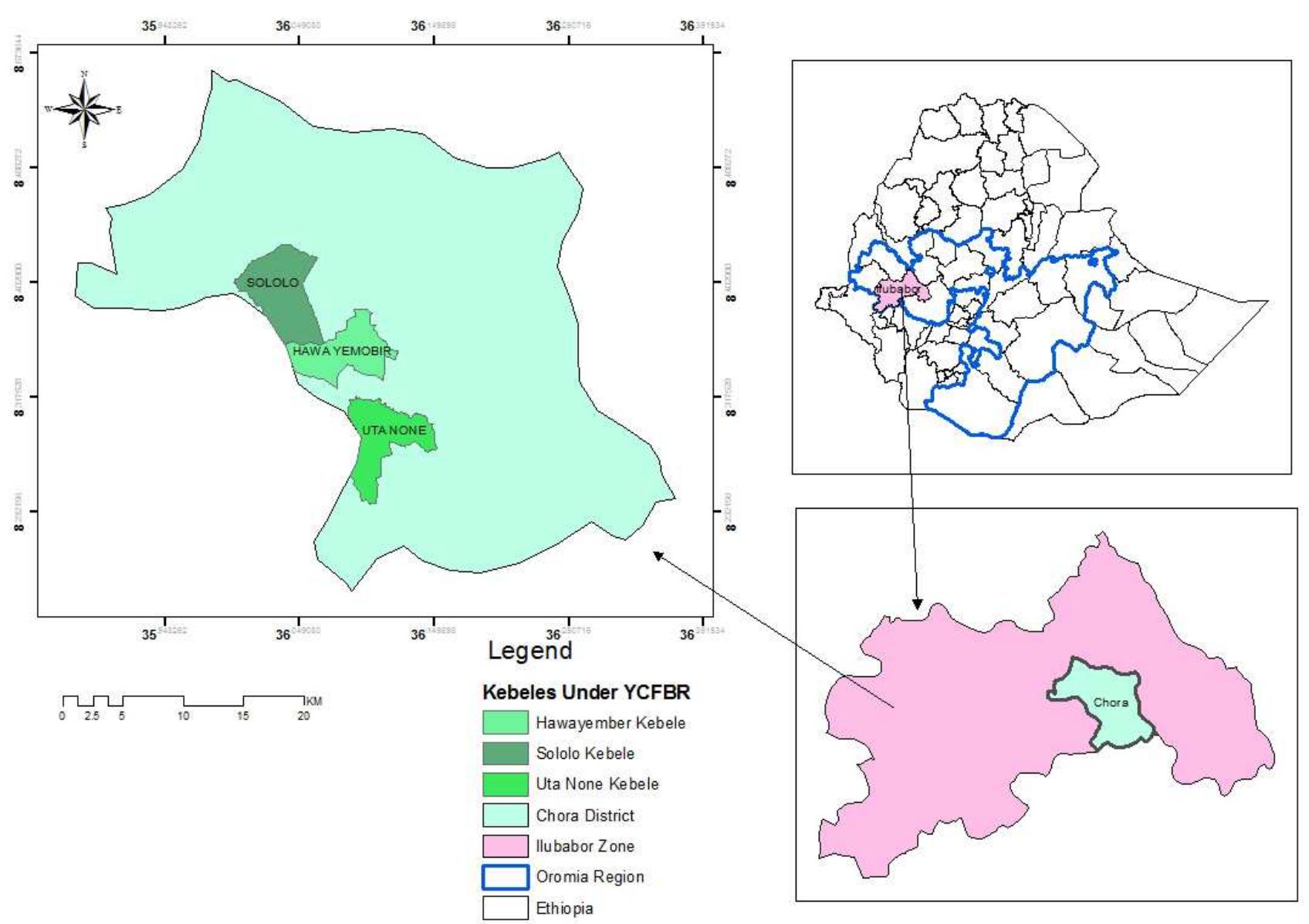

Figure 1. Map of the study area

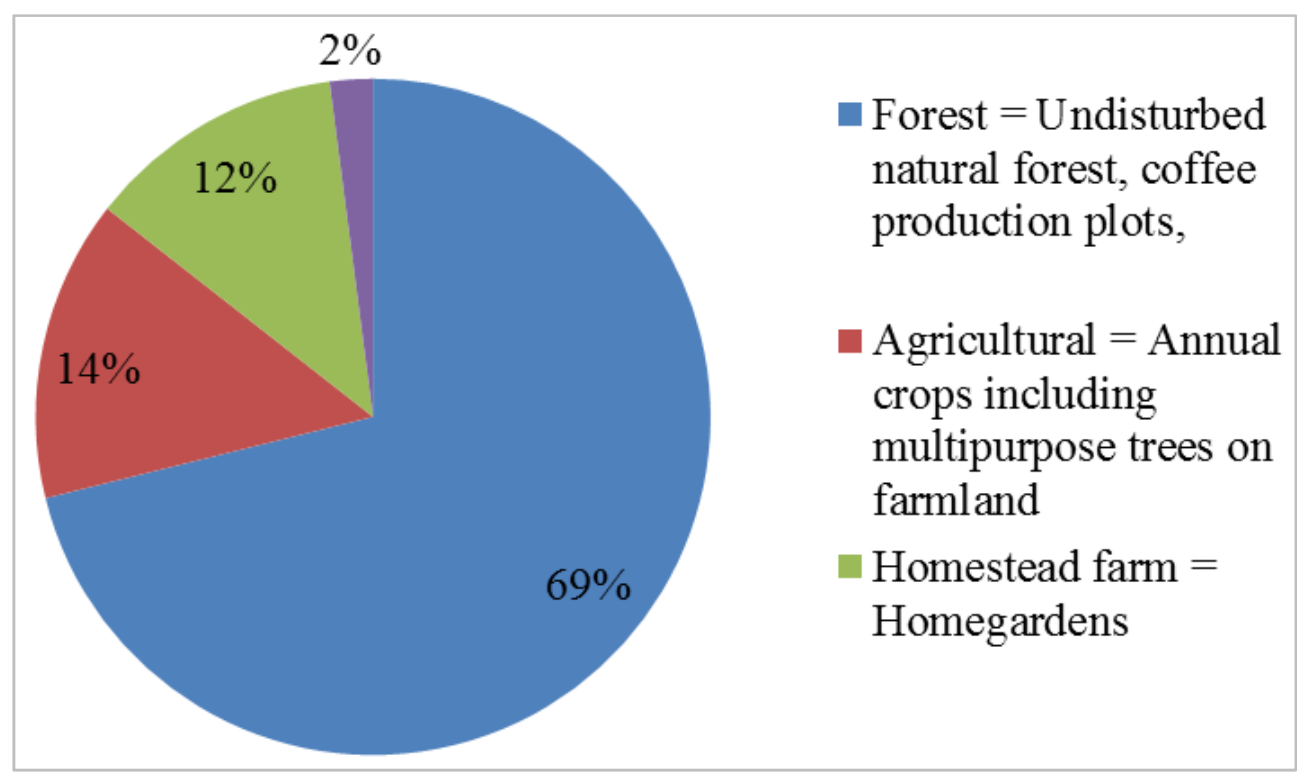

Figure 2. Major land-use type in YCFBR area (\%) adapted from [5]. 


\section{(iii) Transitional Zone of YCFBR and Households Livelihood}

The transition area is found adjacent to the buffer zone and it is composed of agricultural land, wetland, grassland, settlement area and fragments of forest land and covers area of 117,736 ha. It is the place of residence for all the human population in the biosphere reserve, the development organizations and local institutions. Around 154,300 permanent residents live in the transition areas of the Biosphere, including urban and rural settlements of whom the majority depend on agriculture for their livelihoods. Most income for the livelihood of the population of the area comes from the transition area [46].

The main livelihood source of the Yayo households is coffee-based agriculture, which employs over $90 \%$ of the active labour of the area [5]. Most coffee plots are small, however it is estimated that more than $60 \%$ of the population depends on coffee production and coffee-related activities, such as collection, processing and marketing [20, 24]. Besides coffee and the other cash crop khat, smallholders produce annual crops, such as Zea mays, sorghum (Sorghumbicolor), teff (Eragrostis teff), and other cereals and pulses.

Farmers in the transitional zone own and cultivate land and are free to use it as they like. Many of them also own patches of private coffee forest in the transitional zone and have been assigned patches in the buffer zone. The agricultural landscape of the transition zone includes some of the semi-forest coffee production areas, garden coffee, small coffee plantations, cropland, and grazing land. Even though the area has abundant resources, which can support the local livelihood and the quality of important products like coffee, honey and spices, it has a large potential for improvement, mainly due to lack of improved production and processing technologies. The transition part of YCFBR has a lot of spices and herbs flora; among Korarima (Aframomum korarima) spice ranks first and other spices such as chilies, ginger, turmeric, coriander, etc. are grown widely [13]

The agricultural landscape of smallholder surrounding the forest area is also important for the conservation of cultivated many horticultural crop landraces. The smallholder farmers in the this area grow cereals, legumes, coffee, vegetables, fruits, root and tubers, spices and herbs and other crops together either as sole crop or in a combinations others in the homegardens with the shade trees [46] as cited in [13].

YCFBR area is forest environment, its arabica species, and makes a meaningful contribution to the livelihoods of hundreds of smallholder farmers [8]. Also, according to [31], the farmers cultivate diverse crops in YCFBR areas. They do not solely rely on one cereal but many households cultivate a mix of two to four different staple items such as maize, sorghum, millet, wheat, barley and teff (Eragrostis teff).

In addition they grow different pulses (beans, peas, and chickpeas), root and tuber crops (potato, sweet potato, beetroot, carrot, anchote and enset (Ensete venricosum), vegetables (hot/green pepper, tomato, pumpkin, Ethiopian kale, cabbage, Tarro, Abrango, onion and garlic), fruits (avocado, banana, mango, papaya, orange, lemon, and jackfruit) and a variety of spices (ginger, Ethiopian cardamom (Aframomum corrorima), and turmeric. The most important cash crops in the area are coffee and khat (Catha edulis); sugarcane and eucalyptus tree are also cultivated in the study area. Livestock and their products are also common commodities produced in the area. The main livestock includes: cows (milk production), bulls, sheep and goats, poultry and apiculture. Maize and coffee are the dominant commodities produced with the aim of consumption and market, respectively.

\subsubsection{Homegardens in YCFBR}

The traditional agroforestry systems in YCFBR in southwestern Ethiopia are among the most widespread and best performing agroforestry practices, and support the livelihoods of the local population while maintaining environmental integrity [5]. Homegardens of transitional zone of YCFBR encompass a mix of useful plants including staple crops like Enseteventricosum and Zea mays, tuber and root crops, e.g., anchote (Coccinia abyssinica), taro (Colocasia antiquorum), potato (Solanum tuberosum) and sweet potato (Ipomoea batatas), leafy and othervegetables, e.g., kale (Brassica oleracea) and hot pepper (Capsicum frutescens); exotic fruits, e.g., papaya (Carica papaya), mango (Mangifera indica) and avocado (Persea americana), and some pulsecrops, e.g., haricot bean (Phaseolus vulgaris) and lima bean (Phaseolus lunatus) [13, 25].

Species found in homegardens do not show a predetermined spatial arrangement, with theexception of small plantations of Catha edulis. Rather, the location of individual plants and cohorts israndom and conveniently determined by the farmer's needs. For instance, spices are planted closerto the homestead, or shade-loving crops under fruit trees. In addition, species density is also variable depending on the household and market demand, and generally tends to increase based on the farmers aim to introduce and test potential useful species gathered elsewhere [25].

\subsection{Methods}

\subsubsection{Study Site Selection}

The study sites (Kebeles, the smallest administrative unit in Ethiopia) and the district was selected purposefully. Three Kebeles (Hawayember, Sololo and Uta None) were selected for this study. The selection was based on their inclusion in YCFBR, and widespread practice of homegarden for the objective stated.

\subsubsection{Sample Size and Sampling Techniques}

45 homegardens from three Kebele (15 from each Kebele) (Table 1) were selected by simple random sampling method for homegarden plant inventory, following the method used by [39]. The resulting sampling distribution of the study site by Kebeles is shown as in Table 2 below. 
Table 1. Total population and sample used for the study.

\begin{tabular}{ll}
\hline Kebele & HG per Kebele \\
\hline Hawayember & 15 \\
Sololo & 15 \\
Uta None & 15 \\
& 45 \\
\hline
\end{tabular}

$\mathrm{HG}=$ Homegerden

\subsubsection{Data Collection Methods}

To assess the diversity and composition of plant species, a total of 45 homegardens (15 from each Kebele) were randomly selected. Three plots with the size of $5 \times 5 \mathrm{~m}$; in each homegarden were established. The three plots were taken from right, left and back side of the homegarden in order to assess the whole plant species following [6].

Plant species identification was supported by a local taxonomist and use of the following specialized literatures: flora of Ethiopia and Eritrea, a glossary of Ethiopian plant names, and 'Useful trees and shrubs of Ethiopia' [29, 11, 21, 22].

Field observation was undertaken.

Table 2. Summary and descriptions of instruments.

\begin{tabular}{|c|c|c|c|c|}
\hline No & Types of instruments & Target group & Number of target group representations & Types of sampling \\
\hline & Plant inventory & Selected homegarden & 45 & Simple random sampling \\
\hline
\end{tabular}

\subsubsection{Data Analysis}

The plant inventory data were organized using Microsoft excels 2016. Then, floristic composition was analyzed for species diversity using equations of the parameters such as frequencies, relative frequencies, Shannon and Wiener, Simpson's and evenness indices for species diversity and Sorenson's similarity indices were computed for the 15 homegardens of each Kebele following [44, 30].

i. Frequency

Frequency describes the distribution of a species through a stand. It is determined by calculating the percentage of plots/quadrats in a sample area in which a given species occurs by following [34].

$$
\mathrm{F}=\frac{\text { Number of homegardens in which a species occurs } 100}{\text { Total number of sampled homegardens }}
$$

\section{ii. Relative Frequency}

Relative Frequency (RF) is the distribution of one species in a sample relative to the distribution of all species. This was calculated by the formula:

$$
\mathrm{RF}=\frac{\text { The frequency of a species in the homegardens Ax } 100}{\text { Total frequency of all species in the sampled homegarden }}
$$

iii. Species richness

Species richness was determined by recording plant species in a study area, regardless of abundance.

iv. Shannon Wiener diversity index

Shannon's Index is the most applicable index of diversity and accounts for both richness and evenness of the species present [44]. Thus, species diversity is a product of species richness and evenness or equitability. Species diversity index provides information about species endemism, rarity, and commonness. Measures of species diversity are usually seen to be key indicators for the wellbeing of ecological systems [23]. The diversity of each site is calculated using this index based on the frequency of species as the input source. The Shannon Diversity Index $\left(\mathrm{H}^{\prime}\right)$ is calculated using the following formula.

$$
\mathrm{H}^{\prime}=-\Sigma \mathrm{Pi} * \ln \mathrm{Pi}
$$

Where, $\mathrm{H}^{\prime}=$ Index of species diversity, $\mathrm{Pi}=$ No. of individual of one species/Total no. of individuals in the samples

v. Simpson's Dominance index $(\lambda)$

Simpson's Dominance index $(\lambda)$ was used to describe the dominance i.e. the degree that a community is dominated by one or a few common species.

$$
\lambda=\Sigma(\mathrm{pi}) 2
$$

The index measures dominance on a $0-1$ scale. If only one species is present in the community, $\mathrm{Pi}=\lambda=1$ will be the maximum value.

vi. Species evenness index

Evenness index $\left(\mathrm{E}=\mathrm{H}^{\prime} / \mathrm{lnS}\right)$ was used to describe the diversity in terms of evenness i.e. how equally abundant the species were in the homegardens. This standardizes evenness on a scale from $0-1$.

$$
\mathrm{E}=\frac{\mathrm{H}^{\prime}}{\operatorname{lns}}
$$

Where, $\mathrm{E}=$ Species evenness index, $\mathrm{H}^{\prime}=$ Shanon-Winner index of diversity, $\mathrm{S}=$ Total no. of species

vii. Similarity among homegardens

Sorenson's similarity ratio was used to evaluate the similarity between plant communities in homegardens of the three Kebeles. It was calculated with the help of formula by [37] and [30]. This index measures the degree to which the species composition of quadrats or samples is alike, whereas the dissimilarity coefficient assesses which two quadrats or samples differ in composition. Sorensen's index is the most common binary similarity coefficient because it relies on presence or absence data.

$$
\mathrm{SS}=\frac{2 \mathrm{a}}{2 \mathrm{a}+\mathrm{b}+\mathrm{c}} .
$$

Where $\mathrm{a}=$ number of species common to both quadrats/samples $b=$ number of species unique to quadrat/sample $1 \mathrm{c}=$ number of species unique to quadrat/sample 2 .

\section{Results and Discussion}

\subsection{Plant Diversity}

A total of 79 plant species belonging to 41 families were 
recorded from homegardens of the study area. The most commonly represented family was Rutaceae containing the largest number of species ( 7 species), followed by Fabaceae and Rosacaea that represented six and five species respectively (Table 3 ). This result is slightly similar with a finding of [43], who reported that a total of 94 plant species representing 41 families in homegardens of the surrounding area, around YCFBR. Similarly, the least plant species numbers were recorded in 25 families those representing one species and four families each containing two species (Table 3).

Table 3. Plant families with their respective number of species.

\begin{tabular}{llll}
\hline Family name & $\begin{array}{l}\text { Number of } \\
\text { species }\end{array}$ & Family name & $\begin{array}{l}\text { Number of } \\
\text { species }\end{array}$ \\
\hline Rutaceae & 7 & Capparidaceae & 1 \\
Fabaceae & 6 & Boraginaceae & 1 \\
Rosacaea & 5 & Caricaceae & 1 \\
Euphorbiaceae & 4 & Chenopodiaceae & 1 \\
Asteraceae & 3 & Celastraceae & 1 \\
Acanthaceae & 3 & Convolvulaceae & 1 \\
Brassicaceae & 3 & Cupressaceae & 1 \\
Lamiaceae & 3 & Dioscoreaceae & 1 \\
Moraceae & 3 & Dracaenaceae & 1 \\
Musaceae & 3 & Lauraceae & 1 \\
Solanaceae & 3 & Lythraceae & 1 \\
Zingiberaceae & 3 & Malvaceae & 1 \\
Alliaceae & 2 & Meliaceae & 1 \\
Cucurbitaceae & 2 & Myrsinaceae & 1 \\
Myrtaceae & 2 & Phytolaccaceae & 1 \\
Rubiaceae & 2 & Poaceae & 1 \\
Amaranthaceae & 1 & Proteaceae & 1 \\
Anacardiaceae & 1 & Rhamnaceae & 1 \\
Annonaceae & 1 & Ulmaceae & 1 \\
Apocynaceae & 1 & Verbenaceae & 1 \\
Araceae & 1 & & \\
\hline & & & 1 \\
\hline
\end{tabular}

Homegarden plant diversity assessment, Chora district, 2017

The Shannon Wiener index shows a higher diversity of plant species in Hawayember homegarden $\left(\mathrm{H}^{\prime}=3.31\right)$ as compared to the homegardens of Uta None $\left(\mathrm{H}^{\prime}=3.28\right)$ and Sololo $\left(\mathrm{H}^{\prime}=3.22\right)$ (Table 4$)$. The findings of this study slightly disagree with findings of [14], in which they reported $\mathrm{H}^{\prime}=1.43$ in homegarden of Basketo Special Woreda in Southern Ethiopia. This difference might be because of agroecological variation of the two sites. The diversity index was least in the Sololo homegardens that means only a few species plants were more abundant. Species like Catha edulis, Coffea arabica, Colocasia esculent, Ipomoea batata, and Brassica napus were more abundant than others in the Sololo Kebele homegardens, but many other fruit and tree species were equally abundant in the Hawayember and Uta None homegardens like Mangifera indicia, Musa paradisiaca, Citrus sinensis, Carica papaya, Eucalyptus comaldulesis, Cordia africana, and Croton macrostachys etc.

The dominance index also shows that only a few species dominated the homegardens in Sololo $(\lambda=0.058)$ as compared to Hawayember $(\lambda=0.049)$ and Uta None $(\lambda=0.052)$ homegardens. The evenness index shows that in Hawayember homegardens most of the species are almost equally abundant $(E=0.9)$ than Sololo $(E=0.86)$ and Uta None $(\mathrm{E}=0.85)$, (Table 4).

Table 4. Species richness, Shannon and evenness indexes of plant species in homegarden agroforestry per Kebeles.

\begin{tabular}{llllll}
\hline Kebele & Total & Richness & $\begin{array}{l}\text { Shannon } \\
\text { index }\end{array}$ & $\begin{array}{l}\text { Evenness } \\
\text { index }\end{array}$ & $\begin{array}{l}\text { Simpsons } \\
\text { index }\end{array}$ \\
\hline Hawayember & 3859 & 39 & 3.31 & 0.90 & 0.049 \\
Sololo & 4304 & 42 & 3.22 & 0.86 & 0.058 \\
Uta None & 5412 & 48 & 3.28 & 0.85 & 0.052 \\
Mean & 4525 & 43 & 3.27 & 0.87 & 0.053 \\
SD & 799.74 & 4.58 & 0.05 & 0.03 & 0.005 \\
\hline
\end{tabular}

$\mathrm{SD}=$ Standard deviation

Homegarden plant diversity assessment, Chora district, 2017

\subsubsection{Growth Habits and Origin of Plant Species}

Plants biodiversity in the homegardens of the study areas were grouped into four life forms. Accordingly, among the recorded 79 plant species herbaceous, trees, shrubs, and climbers plants account for $34 \%, 30 \%, 27 \%$, and $9 \%$ respectively. In all the three Kebeles, herbaceous plants followed by trees and shrubs dominate homegarden (Table 5). This is also in agreement with the findings of [36], which stated that the grand total number of common plant species comprising perennials, annuals and seasonal.

In terms of origin, the studied homestead flora consists of both native and exotic species. About 47 (59\%) species were identified as exotic while the rest $32(41 \%)$ were indigenous plant species; among which fruits account for the larger number (12 species) of the exotic plants, whereas most of the medicinal and woody species were native plants (Appendix 8). The fact that the majority of homegarden plants were exotic might be attributed to their market profitability and management suitability like fast growth ability of the species. This result is in agreement with [25], that reported a higher number of exotic species observed in homegarden, in comparison with the majority of native species (about 70\%) plant species from the two practices, namely multistoreycoffee-system and multipurpose-trees on-farmland in the same area, around Yayo, southwest Ethiopia.

Table 5. Composition of different plant habits (growth form) across the three Kebeles.

\begin{tabular}{lllll}
\hline Kebele & Tree & Shrub & Herb & Climber \\
\hline Hawayember & 14 & 7 & 17 & 1 \\
Sololo & 13 & 8 & 19 & 2 \\
Uta None & 16 & 8 & 22 & 2 \\
Overall & $24(30 \%)$ & $21(27 \%)$ & $27(34 \%)$ & $7(9 \%)$ \\
\hline
\end{tabular}

Homegarden plant diversity assessment, Chora district, 2017

\subsubsection{Floristic Composition}

The most common plant species in occurrence was Coffea arabica which occurred in 39 homegardens (86.7\%) followed by Persea americana, Catha edulis and Ensete ventricosum $(68.9 \%),(64.4 \%)$ and $(62.2 \%)$ respectively (Table 6 and 
Appendix 9). This result is consistent with [2], which reported Coffea arabica as the most frequent species occurring in all $(100 \%)$ of the gardens, in Sidama, Southern Ethiopia. Also, the above findings are in line with the findings of [10], stating that the main structural arrangements in most homegardens are primarily coffee arabica mixed with trees and shrubs. Members of the focus group discussion and the owners of the garden revealed that enriching the homegarden with different plant species in the area is mostly based on their livelihood contribution. The more the plant species contribute to livelihood, the more the households value them for conservation in homegarden.

Among those species, Brassica napus were herbs with considerable use as family food, followed by Citrus sinensis and Musa sapietum those are among the most prominent fruit tree species mainly used for income generation for a family, occurring in the top 10 speciesin homegardens of the area. In the same manner, this study was found out that Catha edulis as one of the top five most abundant homegarden plant components in homegardens of the area (Table 6). This Catha edulis expansion in the traditional homegarden of the area could be probably taken as one of the most plant diversity declining cause emerging in recent days. The conversation held during the focus group discussion also imply that farmers attitudes are being inclined towards of intensively enriching their garden with Catha edulis with the aim of earning more money and /or intentionally to escape from homegarden food crops (fruit bearings) damage by wildlife (Baboons and Monkeys) which are recently being increased rapidly in the area. This result is in agreement with a similar study conducted in the same area around YCFBR by [33], stated that farmers were concerned about wildlife damage to vegetables in coffee forests, negative effects on coffee trees and their root systems and potentially deteriorating coffee yields, and low performance of vegetables under shade.

Table 6. Top 10 plant species in frequency across homegardens of chora district.

\begin{tabular}{llll}
\hline Scientific name & Local name (AO) & Frequency & \% Frequency \\
\hline Coffee arabica & Buna & 39 & 86.67 \\
Persea americana & Avokaadoo & 31 & 68.89 \\
Catha edulis & Caatii & 29 & 64.44 \\
Ensete ventricosum & Qoccoo & 28 & 62.22 \\
Hypoestes restate & Darguu & 27 & 60 \\
Brassica napus & Raafuu Habashaa & 26 & 57.78 \\
Achyranthes aspera & Maxxannee & 25 & 55.56 \\
Citrus sinensis & Burtukaana & 24 & 53.33 \\
Musa sapietum & Muzii faranjii & 24 & 53.33 \\
Woodfordia uniflora & Tuufoo & 24 & 53.33 \\
\hline
\end{tabular}

$\mathrm{AO}=\mathrm{Afan}$ Oromo.

The above result is also in agreement with a similar study conducted in south Ethiopia by [17], Stating that the traditional agroforestry homegarden in Ethiopia is being challenged by the transition to monoculture production of new cash crops. Additionally, the study conducted in
Jibithenan District, Ethiopia, showed that Catha edulis as one of the top five most abundant species in homegardens as owners focus to grow few cash crops by neglecting other beneficial crops that could reduce the diversity of species managed in homegardens [35]. These results is also in agreement with [32], who reported that homegarden diversity is constantly changing both as part of adaptive traditional practices and as traditional systems are abandoned. Again, this result is supported by Scales and Marsden (2008), stating that the anthropogenic influences, increased prevalence of cash crops are the issue that has received the most attention.

\subsubsection{Species Similarity Among Homegardens}

Sorenson's similarity index showed that moderate plant species similarity ( $52 \%$ to $66 \%$ ) in homegardens of the three study Kebeles. More specifically, Sololo and Uta None homegardens are more similar in floristic composition (66\%), than the Similarity of the two sites (Sololo and Uta None) with Hawayember by $52 \%$ and $56 \%$ respectively (Table 7 ). This could be possibly because of the closeness of the two Kebeles Sololo and Uta None to the natural forest areas, as compared to Hawayember which is a little bit far away from the forest area.

Table 7. Plant species Similarity among homegardens of the three study sites.

\begin{tabular}{llll}
\hline Site & Hawayember & Sololo & Uta None \\
\hline Hawayember & 1 & & \\
Sololo & 0.56 & 1 & \\
Uta None & 0.52 & 0.66 & 1 \\
\hline
\end{tabular}

\subsubsection{Food Crop Raised by the Owners of Homegardens}

The homegarden flora in the study area is composed of both food and nonfood plants, accounting for about $57 \%$ and $43 \%$ of the recorded total of species respectively (Appendix 8). Among the food crops fruit constitute the largest number (18), followed by spices and root and tuber plant species consisting 9 and 5 respectively, while the remaining were field crops cereals, pulses, and oils, whereas from non-food plant species accounting $43 \%$ medicinal plants, Shade plants, and construction and fuelwood etc were recorded (Appendix 8 ). These imply that most of the homegarden plant species were edible and make significant contributions to the nutritional well-being.

This result is in agreement with [6], conducted a species inventory of the YCFBR across the 3 zones and identified 220 plant species, of which 84 are edible and widely available in the reserve; a large number are highly nutritious, especially the indigenous green leafy vegetables.

Similarly, this finding is consistent with the findings of [45], that People that manage homegardens for multiple goods to satisfy their social, cultural and economic needs, mainly food. This result is similar to the findings of [39], in southern Ethiopia around Hawassa stating that the largest food crops as fruit, accounting for about 23\%. Also, this result is agreed with the findings of [38], that reported People that manage homegardens get multiple goods to satisfy their social, cultural and economic needs, mainly food. 
According to focus group discussion, plant species richness in homegarden is significantly increased in summer season during peak rainy season of the area. Importantly many herbaceous crops like Brassica napus, maize (Zea Mays), Phaseolus vulgaris; sorghum and pumpkin (Cucurbita pepo) are grown from June to October in most cases. Thus, the diversity composition of homegarden agroforestry increases significantly during this growing season of a year (Figure 3). This result is also in agreement with [41], that reported significant amounts of food-producing cultivated plants and nutrient supplying homegarden products are more available during the main rainy season between June and September at Eastern Harerge Ethiopia, around Kombolcha.

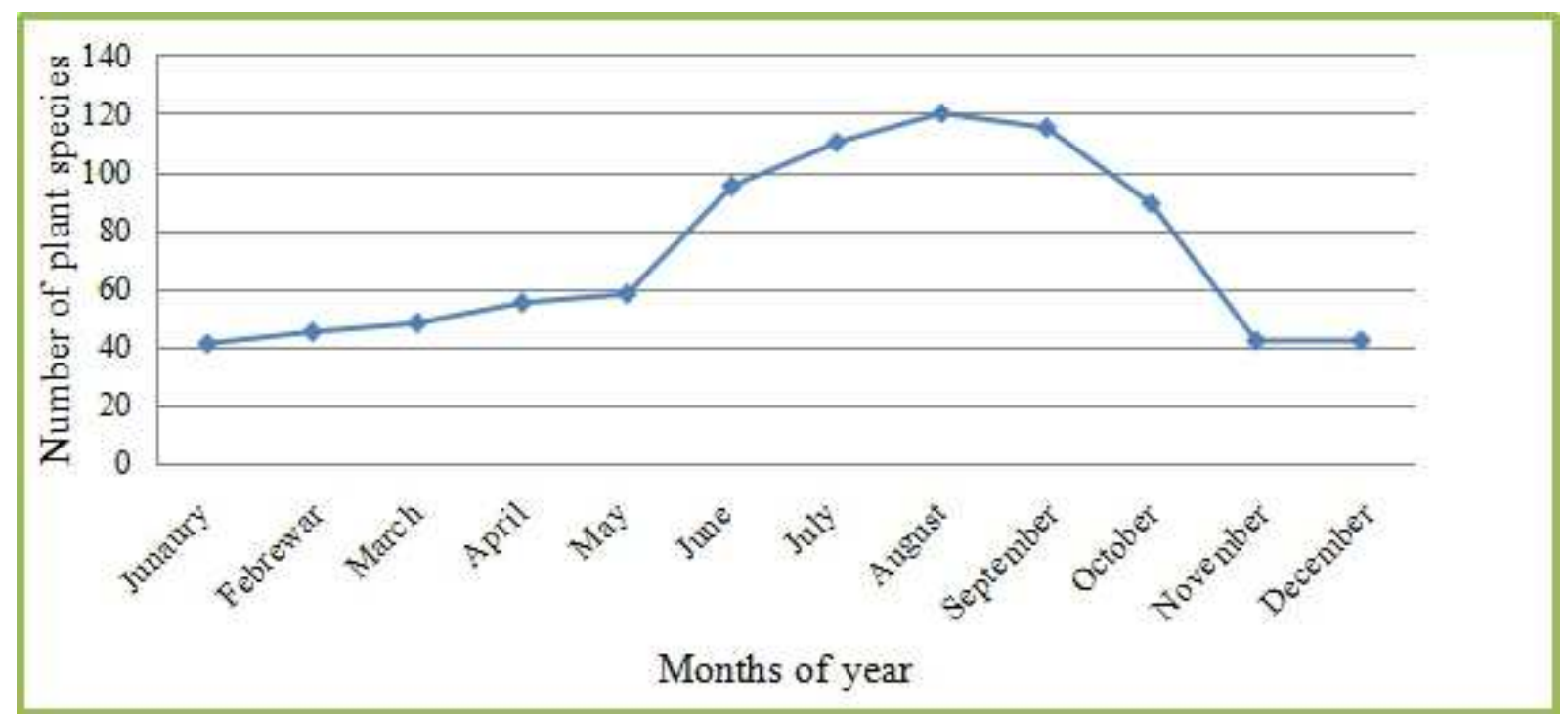

Figure 3. Plant species richness variation throughout the year.

\subsection{Limitation of the Research}

Even though this research was carefully prepared, I'm still aware of its limitations and shortcomings. First of all, the research was conducted based the data collected for three months, which is not enough for the researcher to assess enough information on the homegarden role. It would be better if it was done in a longer time. Second, the population of the experimental group is small; only forty five homegardens might not represent the existing homegarden practices in the biosphere reserve. Third, it might give useful information about the role of homegarden to plant biodiversity conservation; even if it seems not to provide enough evidence of the exact role played by homegarden.

\section{Conclusions and Recommendation}

\subsection{Conclusions}

Homegarden agroforestry practices in YCFBR plays a remarkable role in biodiversity conservation in transitional (utilization zone) of the biosphere. The results of the study revealed that homegarden agroforestry practices in the present study area have been providing multiple benefits and playing significant contribution for the conservation of plant biodiversity and thereby sustainability of the natural resources conservation in the area. The society in the area mainly dependent on diverse plants of different uses in the system for food sources of the family. However, more of the plant species were exotic species in their origin and concentration on few species in the garden were observed. Cultivation of cash crop production particularly, coffee arabica and Catha edulis in homegarden agroforestry practices are attracting more attention of the farming households with the objective of maximizing their cash benefit and concurrently to escape from increased wildlife damage to food crop components in the garden. These situations are happening at the expense of species diversity and bringing a reduction in food provision for poor rural households. Thus, plant biodiversity conservation have been affected. Yet, clear capacity exists to make a homegarden contribution more effective towards of plant biodiversity conservation.

\subsection{Recommendations}

Based on the findings of this study, the following recommendations are suggested:

1) Attention should be given to make homegarden more effective in biodiversity conservation.

2) The composition of homegardens plant species in Chora district is dominated by exotic plant species, thus, planting of indigenous plant species that have better qualities and multiple outputs need to be promoted.

3) Improving locals' awareness on homegarden biodiversity conservation roles to increase floristic diversity and diversity preservation in the practice should be encouraged.

4) Promotion of homegardens should be included in the programmes of conservation agency and others 
concerned bodies to enhance the conservation plant diversity in homegarden for conservation of natural resources on a basis sustainable in the area.

5) Further study is recommended and needed to find available opportunities in supplying plant varieties of ecological and locals' needs.

\section{References}

[1] Abdoellah O. S, Hadikusumah H. Y, Takeuchi K, SatoruOkubo S, and Parikesit. 2006 Commercialization of homegardens in an Indonesian village: vegetation composition and functional changes. Agroforestry Systems 68: 1-13.

[2] Abebe, T. Sterck, F. J. Wiersum, K. F. and Bongers, F. 2013. Diversity, composition, and density of trees and shrubs in agroforestry homegardens in Southern Ethiopia. Agroforestry systems, 87 (6): 1283-1293.

[3] Agbogidi, O. M. And Adolor, E. B. (2014). Homegardens in the Maintenance of Biological Diversity, 8330 (1): 4-19.

[4] Anjulo, A. and Mezgebu, A., 2016. Determinants of Agroforestry Practicing at Fogera District, Northwestern Ethiopia.

[5] Assefa A. D. 2010. Local institutions and their influence on forest resource management in southwest of Ethiopia: The case of Yayo forest. A master thesis, Addis Ababa University.

[6] Bekalo, T. H., Woodmatas, S. D. and Woldemariam, Z. A., 2009. An ethnobotanical study of medicinal plants used by local people in the lowlands of Konta Special Woreda, southern nations, nationalities and peoples regional state, Ethiopia. Journal of Ethnobiology and Ethnomedicine, 5 (1): 26.

[7] Berhanu, A. And Asfaw, Z. 2014. The Role Of Homegardens For Conservation And Sustainable Utilization Of Plant Biodiversity Of Ethiopia.

[8] Bharucha, Z. and Pretty, J. 2010. The roles and values of wild foods in agricultural systems. Philosophical Transactions of the Royal Society of London B: Biological Sciences, 365 (1554): 2913-2926.

[9] CSA, Central Statistical Agency. 2008. Summary and Statistical Report of the 2007 population and Housing Census. Population size by age and sex. Addis Ababa.

[10] Dagar, J. C., and Tewari, V. P., 2017. Evolution of Agroforestry as a Modern Science. In Agroforestry (13-90). Springer, Singapore.

[11] Edwards, S., Tadese, M. and Hedberg, I., 1995. Flora of Ethiopia and Eritrea vol. 2, Part 2: canellaceae to euphorbiaceae. AAU.

[12] Emmett, R. S. and Nye, D. E. 2017. The environmental humanities: a critical introduction. MIT Press.

[13] Etissa, E., Dagnew, A., Ayele, L., Assefa, W., Firde, K., Kiflu, E., Damte, M., Kebede, G., Ayalew, M., Seyoum, M. and Mosie, T., 2016. Fruit crops research in Ethiopia: achievements, current status and future prospects. Agricultural Research for Ethiopian Renaissance.

[14] Feleke, F. B., Berhe, M., Gebru, G. and Hoag, D., 2016.
Determinants of adaptation choices to climate change by sheep and goat farmers in Northern Ethiopia: the case of Southern and Central Tigray, Ethiopia. SpringerPlus, 5 (1), pp. $1-15$.

[15] Galluzzi, G. Eyzaguirre, P., and Negri, V. 2010. Homegardens: neglected hotspots of agro-biodiversity and cultural diversity. Biodiversity and conservation, 19 (13): 35-36.

[16] Gebrehiwot, M. 2013. Recent transitions in Ethiopian homegarden agroforestry (Vol. 21).

[17] Gebrehiwot. (2017). Agroforestry homegardens in Ethiopia: rural livelihoods in transition.

[18] Gole, T. W., Borsch, T., Denich, M. and Teketay, D., 2008. Floristic composition and environmental factors characterizing coffee forests in southwest Ethiopia. Forest Ecology and Management, 255 (7), pp. 2138-2150.

[19] Gole, T. W., Feyera, S., Kassahun, T. and Fite, G., 2009. Yayo coffee forest biosphere reserve nomination form. Ethiopian MAB National Committee, Addis Ababa.

[20] Gole, T. W., 2003, January. Conservation and use of coffee genetic resources in Ethiopia: challenges and opportunities in the context current global situations. In Globalization and Equity: The 4th Annual Global Development Network Conference, Cairo (pp. 19-21).

[21] Hedberg, I., Friis, I. and Edwards, S., 2004. Flora of Ethiopia and Eritrea, Vol. 4, Part 2: Asteraceae (Compositae). Addis Ababa: The National Herbarium and Uppsala: The Department of Systematic Botany.

[22] Hedberg, I., Kelbessa, E., Edwards, S., Demissew, S. and Persson, E., 2006. Flora of Ethiopia and Eritrea, Volume 5: Gentianaceae to Cyclocheilaceae. Addis Ababa, Ethiopia, and Uppsala, Sweden: The National Herbarium, Addis Ababa University.

[23] Heywood, V. H. (1998). The species concept as a sociocultural phenomenon: a source of scientific dilemma. Theory in Biosciences 117: 203-212.

[24] Ilfata, G., 2008. Remote sensing and GIS assisted participatory biosphere reserve zoning for wild coffee conservation: case of Yayu forest (Doctoral dissertation, Addis Ababa University).

[25] Jemal, O., Callo-Concha, D., and van Noordwijk, M., 2018. Local Agroforestry Practices for Food and Nutrition Security of Smallholder Farm Households in Southwestern Ethiopia. Sustainability, 10 (8): 2722.

[26] Jhariya, M. K., Bargali, S. S. and Raj, A., 2015. Possibilities and Perspectives of Agroforestry in Chhattisgarh. In Precious Forests-Precious Earth. InTech.

[27] Jose, S., 2012. Agroforestry for conserving and enhancing biodiversity. Agroforestry Systems, 85 (1): 1-8.

[28] Kassa, G. Abebe, T. and Ewnetu, Z. (2015). Diversity, Density and Management of Trees in Different Agroforestry Practices of Yem Special District, Southern Ethiopia, 38 (1): $1-16$.

[29] Kelecha, W. M., 1987. A glossary of Ethiopian plant names.

[30] Kent, M. and Coker, P., 1992. Vegetation description and analysis. Boca Raton, CRC. 
[31] Kuria, A., Lamond, G., Pagella, T., Gebrekirstos, A., Hadgu, K. and Sinclair, F. L., 2014. Local knowledge of farmers on opportunities and constraints to sustainable intensification of crop-livestock-trees mixed systems in Lemo Woreda, SNNPR Region, Ethiopian highlands.

[32] Nair, 2006. Tropical Homegardens: A Time-Tested Example of Sustainable Agroforestry. Environmental Experts, India Mcneely: 1-9.

[33] Nischalke, S. M., Abebe, M., Wondimagegnhu, B. A., Kriesemer, S. K. and Beuchelt, T., 2017. Forgotten forests? food potential of ancient coffee forests and agroforestry systems in the Southwestern Ethiopian mountains, seen through a gender lens. Mountain Research and Development, 37 (3), pp. 254-262.

[34] Lamprecht, H. 1989. Silviculture in the tropics: tropical forest ecosystems and their tree species: possibilities and methods for their long-term utilization (No. 634.95 L 239s ing.). Eschborn, DE: GTZ.

[35] Mekonen, T. Giday, M. and Kelbessa, E. 2015. Ethnobotanical study of Homegarden plants in Sebeta-Awas District of the Oromia Region of Ethiopia to assess use, species diversity, and management practices. Journal of Ethnobiology and ethnomedicine, 11 (1): 64.

[36] Panda, N. K. Bhol, N., and Nayak, A. (2018). Spatiotemporal arrangement of plants and livestock in the HGs of coastal Odisha, 7 (1): 814-819.

[37] Peet, R. K. 1974. The measurement of species diversity. Annual review of ecology and systematics, 5 (1): 285-307.

[38] Pulido, M. T., Pagaza-Calderón, E. M., Martínez-Ballesté, A., Maldonado-Almanza, B., Saynes, A. and Pacheco, R. M., 2008. Homegardens as an alternative for sustainability: challenges and perspectives in Latin America. Current topics in ethnobotany, 37: 1-25.
[39] Regassa, R., 2016. Useful plant species diversity in homegardens and its contribution to household food security in Hawassa city, Ethiopia. African Journal of Plant Science, 10 (10): 211-233.

[40] Schmitt, C. B., Senbeta, F., Denich, M., Preisinger, H. and Boehmer, H. J., 2010. Wild coffee management and plant diversity in the montane rainforest of southwestern Ethiopia.

[41] Semu, A. (2018) The Study of Homegarden Agrobiodiversity, Practices of Homegardening and Its Role for In-Situ Conservation of Plant Biodiversity in Eastern Hararghe, Kombolcha Town Oromia Regional State Ethiopia. Open Journal of Forestry, 8, 229-246. doi: 10.4236/ojf.2018.82016. African Journal of Ecology, 48 (1): 78-86.

[42] Senbeta, F., Schmitt, C., Denich, M., Demissew, S., Velk, P. L., Preisinger, H., Woldemariam, T. and Teketay, D., 2005. The diversity and distribution of lianas in the Afromontane rain forests of Ethiopia. Diversity and Distributions, 11 (5): 443-452.

[43] Seyoum Aragaw, H., 2017. Nutritional potential of underutilized edible plants in agroforestry systems of Yayo, Southwestern Ethiopia (Doctoral dissertation, University of Bonn).

[44] Shannon C, E. Wiener, W. (1949). The Mathematical Theory.

[45] Van Asten, P. Ochola, D. Wairegi, L. Nibasumba, A. Jassogne, L. and Mukasa, D. 2013. Coffee-banana intercropping: Implementation guidance for policymakers and investors.

[46] Teketay, D., Lemenih, M., Bekele, T., Yemshaw, Y., Feleke, S., Tadesse, W., Moges, Y., Hunde, T. and Nigussie, D., 2010. Forest resources and challenges of sustainable forest management and conservation in Ethiopia. In Degraded Forests in Eastern Africa (pp. 31-75). Routledge. 